DOI: https://doi.org/10.36910/6775-2524-0560-2021-43-19

УДК 519.866

Решетняк Тетяна Вікторівна, старший викладач

https://orcid.org/0000-0001-9025-3877

Нечволода Людмила Володимирівна, к.т.н., доцент

https://orcid.org/0000-0002-7584-6735

Крикуненко Катерина Миколаївна, асистент

https://orcid.org/0000-0003-1530-216X

Донбаська державна машинобудівна академія, м. Краматорськ, Україна

\title{
ЗАСТОСУВАННЯ ТЕОРІЇ МАССОВОГО ОБСЛУГОВУВАННЯ ДЛЯ ОПТИМІЗАЦІЇ УПРАВЛІННЯ ТЕХНІЧНИМ ОБСЛУГОВУВАННЯМ І РЕМОНТОМ ОБЛАДНАННЯ
}

Решетняк Т.В., Нечволода Л.В., Крикуненко К.М. Застосування теорії масового обслуговування для оптимізації управління технічним обслуговуванням і ремонтом обладнання. Представлено використання методів теорії масового обслуговування для оптимізації управління технічним обслуговуванням та ремонтом обладнання. Процеси обслуговування та ремонту обладнання на машинобудівному підприємстві було розглянуто з позиції багатоканальної системи масового обслуговування з чергою. Було використано ЕВМ для автоматизації розрахунку необхідної кількості ремонтних вузлів для мінімізації часу простою обладнання у черзі на ремонт та мінімізації витрат.

Ключові слова: моделювання, система масового обслуговування, обладнання, ремонт, інтенсивність потоку, витрати, верстати, вузли.

Решетняк Т.В., Нечволода Л.В., Крикуненко К.Н. Применение теории массового обслуживания для оптимизации управления техническим обслуживанием и ремонтом оборудования. Представлено использование методов теории массового обслуживания для оптимизации управления техническим обслуживанием и ремонтом оборудования. Процессы обслуживания и ремонта оборудования на машиностроительном предприятии были рассмотрены с позиции многоканальной системы массового обслуживания с очередью. Было использовано ЭВМ для автоматизации расчета необходимого количества ремонтных узлов для минимизации времени простоя оборудования в очереди на ремонт и минимизации затрат.

Ключевые слова: моделирование, система массового обслуживания, оборудование, ремонт, интенсивность потока, затраты, станки, узлы.

Reshetniak T.V., Nechvoloda L.V., Krykunenko K.M. Appliyng of queuing theory to optimize the management of maintenance and repair of equipment. The use of queuing theory methods for optimization of equipment maintenance and repair management is presented. The processes of maintenance and repair of equipment at a machine-building enterprise were considered from the standpoint of a multichannel queuing system with a queue. A computer was used to automate the calculation of the required number of repair units to minimize equipment downtime in the queue for repair and minimize costs.

Key words: modeling, queuing system, equipment, repair, flow rate, costs, machine tools, units

Постановка наукової проблеми. Актуальність теми обумовлена тим, що системи масового обслуговування (СМО) виробничих процесів $є$ невід’ємною складовою сучасних промислових підприємств. Прикладами СМО можуть бути підприємства, що займаються виготовленням різних видів продукції, в тому числі і машинобудівні. Кожна $з$ цих систем складається 3 деякої кількості обслуговуючих вузлів (апаратів обслуговування). Прикладами таких апаратів можуть виступати як робітники, так машини і верстати. Моделювання СМО дозволяє визначити показники функціонування системи, що обслуговує. В майбутньому така інформація буде використовуватися для вибору належного рівня обслуговування.

Дослідивши процеси, що відбуватимуться у виробничій СМО, можна прогнозувати якість роботи системи. Змінюючи параметри системи, можна простежити, як змінюється ефективність обслуговування та прийняти рішення щодо збільшення продуктивності роботи. Таким чином $\epsilon$ можливість зробити розрахунок оптимальної кількості апаратів, щоб час простою кожного апарату системи був мінімальний, а час зайнятості - максимальний.

Системами (моделями) масового обслуговування називають математичні моделі систем, які призначені для обслуговування вимог, що надходять через випадкові проміжки часу, причому тривалість обслуговування в загальному випадку також випадкова.

Формально під системою масового обслуговування розуміють складну систему, що формується 3 одного або декількох джерел запитів (заявок, вимог) для виконання певних дій (обслуговування), декількох приладів обслуговування (ліній обслуговування, каналів обслуговування), що виконують ці дії відповідно до певних правил (дисципліни обслуговування) за запитами, що надійшли в систему. Характерною особливістю СМО є випадковість процесів, що відбуваються, і можливість утворення черги запитів на обслуговування.

() Решетняк Т.В., Нечволода Л.В., Крикуненко К.М. 
Теорія масового обслуговування - це математичне дослідження таких систем, до яких у випадкові моменти часу надходять вимоги (ззовні або зсередини системи). Система повинна обслужити вимоги, причому тривалість обслуговування в загальному випадку випадкова.

Природа вимог і їх обслуговування залежить від конкретного виду системи. Якщо під вимогами розуміти, наприклад, відмови елементів системи або верстатів і відповідно під обслуговуванням їх заміну або ремонт, то чисельні завдання надійності можна вирішувати методами теорії масового обслуговування.

В даний час гостро стоїть питання про поліпшення якості технічного обслуговування та ремонту обладнання на крупних підприємствах. Тимчасове (чи постійне) знаходження обладнання у непрацездатному режимі напряму пов'язано зі значними витратами на його утримання та недоотриманням прибутку підприємством в цілому. Така тенденція характерна і для підприємств, що випускають машинобудівну продукцію.

Аналіз досліджень. Розроблення практичних завдань масового обслуговування започаткував співробітник Копенгагенської телефонної компанії данський 11 математик А. К. Ерланг (1878-1929 pp.) у період із 1908 по 1922 роки. У 1909 р. було опубліковано його робота «Теорія ймовірностей $\mathrm{i}$ телефонні переговори» та інші, у яких сформульовано перші прикладні завдання телефонії. Ці завдання були пов'язані 3 необхідністю впорядкувати роботу телефонної мережі й розробити методи оцінювання якості обслуговування споживачів залежно від кількості використовуваних пристроїв. Значний внесок зробив Л. Клейнрок, який використовував теорію СМО для дослідження обчислювальних систем [1].

Питання узагальнення методів вирішення різноманітних завдань за допомогою теорії масового обслуговування досліджував математик О. Я. Хінчин у книзі «Математичні методи теорії масового обслуговування», де вперше сформульовані загальні ідеї і методи такої теорії [10]. Подальший розвиток теорії масового обслуговування пов'язаний з ім'ям відомих математиків Б. В. Гнеденко, І. Н. Коваленко [2], А. М. Колмогорова, Н. П. Бусленка [1] та ін [4-11]. Серед зарубіжних авторів потрібно назвати Д. Кенига, Д. Штойян [3], Д. Кендалла, Дж. Літтла.

Метою статті є оптимізація процесу управління технічним обслуговуванням та ремонтом обладнання машинобудівного підприємства за рахунок використання теорії масового обслуговування.

\section{Виклад основного матеріалу й обгрунтування отриманих результатів дослідження.}

Ефективне керування процесом виробництва продукції та розподілом оборотного фонду запасних частин, вузлів і агрегатів, що використовуються при ремонті верстатів, має важливе значення.

У загальному вигляді технологічну систему машинобудівного підприємства (до складу якої входять служби ремонту та обслуговування технологічного обладнання) можна розглядати як деякий функціонал, що характеризує ефективність функціонування об'єкта в середовищі. При цьому статистичні властивості такого функціоналу будуть залежати від стану середовища та поточного стану об'єкта. При структурній адаптації процес визначення структури технологічного обладнання, близької до оптимальної, можна подати в наступному вигляді [5]:

$$
R e_{S}=\left\langle W^{*}, C\left(W^{*}\right)\right\rangle=\left\langle\operatorname{Arg} \min _{W \in E_{W}} Q(W), \operatorname{Arg} \min _{C \in E_{C(w)}} Q(C(W))\right\rangle,
$$

де $\quad W$ - структурні фактори, що змінюються при зміні структури об'єкта адаптації (далі структура);

$C$ - параметри об'єкта, мінливі при зміні його структури;

$E_{W}$ - множина допустимих структур $W$;

$E_{C(W)}$ - множина допустимих параметрів $C$, що відповідають структурі $W$.

При створенні сучасних автоматизованих систем управління підприємством в них повинні бути включені:

- підсистема управління основними фондами;

- підсистема обліку технічного стану обладнання, яка отримує дані від системи диспетчерського контролю;

- підсистема управління технічним обслуговуванням і ремонтом (ТOіP).

Комплексне використання таких підсистем має забезпечувати автоматизацію планування, генерацію мережевих графіків та контроль за реалізацією відповідних заходів 3 обслуговування та підтримки високого рівня продуктивності технологічного устаткування. 
Процес технічного переоснащення машинобудівного підприємства може бути представлений у вигляді узагальненої схеми, яка наведена на рисунку 1 [5].

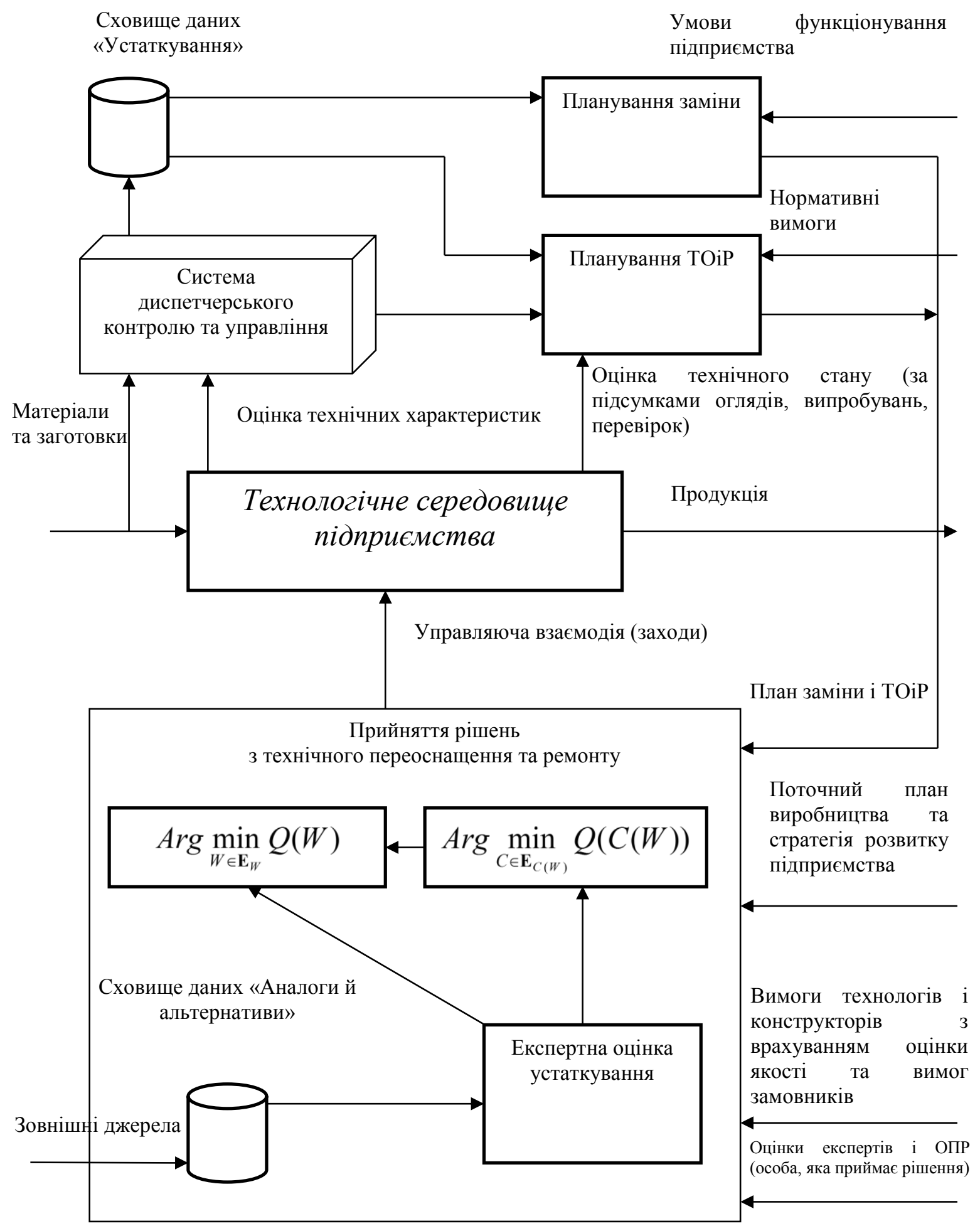

Рис. 1. Узагальнена схема апаратно-програмного комплексу для керування параметрами технологічного середовища

Такий комплекс повинен забезпечувати вибір технічно і економічно обгрунтованого шляху розвитку основних фондів за рахунок вироблення і реалізації керуючих впливів відповідно до результатів структурної адаптації.

Одним із напрямів удосконалення управління процесом адаптації технологічного середовища $\epsilon$ оптимізація діяльності підсистеми ТОіР. У загальному вигляді таку підсистему можна розглядати як 
систему масового обслуговування, а одним з методів вирішення поставленої задачі може служити математичний апарат теорії масового обслуговування.

При аналізі роботи СМО необхідно знати ії основі вхідні параметри:

- інтенсивність потоку заявок - $\lambda$;

- трудомісткість обслуговування однієї заявки - Tp;

- кількість каналів обслуговування - $n$;

- кількість місць очікування - $m$;

- кількість операторів на одному каналі $-d$;

- умови утворення черги.

При описі режиму роботи СМО використовуються проміжні параметри:

- час обслуговування однісї заявки $t 0=T p / d$;

- продуктивність кожного каналу обслуговування $\mu=1 / t 0$ (середня кількість заявок, що обслуговується каналом в одиницю часу);

- приведена інтенсивність обслуговування $\alpha=\lambda / \mu$;

- коефіцієнт загрузки $\beta=\alpha / n[1]$.

Виробничі процеси можуть 3 часом перериватися в результаті часткового або цілковитого виходу 3 ладу окремих вузлів чи цілих агрегатів (станків, верстатів, виробничих ліній тощо), що потребує налагодження цієї виробничої структури. Наперед неможливо передбачити ні час виходу з ладу такої структури, ні час для iї налагодження. Обидві ці величини з випадковими змінними розподілені за експонентним законом відповідно до параметрів $\lambda$ та $\mu(\lambda>0, \mu>0)$.

СМО виробничих процесів є трьох видів, а саме:

- системи масового обслуговування виробничих процесів 3 однією лінією обслуговування $(\mathrm{M} / \mathrm{M} / 1):(\mathrm{GT} / \mathrm{m} / \mathrm{m})$, де символ $\mathrm{GT}$ - це дисципліна черги не регламентована (якщо деякий верстат вийшов $з$ ладу, а робітник-налагоджувач незайнятий в цей момент часу обслуговуванням якогось іншого верстата, то він відразу починає налагоджувати зіпсований верстат, в протилежному випадку утворюється черга на обслуговування з верстатів що вийшли з ладу);

- системи масового обслуговування виробничих процесів 3 декількома лініями обслуговування (M/M/n):(GT/m/m), де робітників-налагоджувачів більше одного;

- системи масового обслуговування виробничого процесу розподільчого типу $(\mathrm{M} / \mathrm{M} / \mathrm{m}):(\mathrm{GT} / \mathrm{m} / \mathrm{m})$, система, в якій декілька споживачів використовують деякий ресурс 3 одного джерела постачання, причому вимоги на постачання цього ресурсу та необхідні об'єми його незалежні між собою [6].

У СМО потік вимог та час обслуговування є випадковими. Всі процеси, що виконуються у СМО мають нерегулярний характер. Тобто бувають моменти часу роботи системи, що утворюється черга 3 верстатів, що очікують обслуговування. Але може виникнути така ситуація, що виникає простій апаратів обслуговування. Встановлення оптимальної (з мінімальними простоями) залежності між числом вузлів і їх продуктивністю (часом обслуговування), характером потоку вимог, правилами роботи системи обслуговування виступає завданням теорії масового обслуговування.

Дуже часто в якості показників ефективності роботи СМО використовуються: показники середнього часу очікування вимоги початку обслуговування; середнього розміру черги на обслуговування; ймовірності того, що в системі обслуговування буде знаходитися певна кількість вимог; середнє число апаратів, зайнятих або вільних від обслуговування, і ряд інших.

Однак не менш важливим $є$ використання економічних показників оцінки ефективності функціонування СМО. Такі показники дають узагальнену характеристику виробничого процесу. В такому разі загальні грошові витрати, пов'язані з простоями верстатів в очікуванні обслуговування, $\mathrm{i}$ витрати на створення та експлуатацію постів (апаратів) зазвичай обираються в якості критеріїв ефективності функціонування СМО.

На деяких машинобудівних підприємствах застосовується агрегатний метод ремонту. В разі наявності несправного верстату, його замінюють на придатний, що береться зі складу. У випадку відсутності на складі агрегатів верстат очікує в черзі на ремонт.

В такому випадку вхідний потік вимог утворюють верстати з несправними агрегатами. Оборотні агрегати в даному випадку є обслуговуючими апаратами. Вся заміна агрегатів здійснюється в порядку надходження вимог. Така СМО може розглядатися як система масового обслуговування з очікуванням.

Задача оптимізації оборотного фонду агрегатів машинобудівного підприємства зводиться до пошуку мінімуму цільової функції [8]: 


$$
z=B_{\text {оч }} A_{\text {н }}+B_{N} A_{c},
$$

$\partial e B_{\text {оч }}$ - витрати у т. грн, що викликані простоєм одного верстата в очікуванні надходження відремонтованого агрегату протягом доби; агрегатів;

$A_{\text {н }}$ - середня кількість несправних верстатів, що очікують надходження відремонтованих доби;

$B_{N}$ - витрати, що викликані невикористанням одного відремонтованого агрегату впродовж

$A_{\mathrm{c}}$ - середня кількість невикористаних агрегатів (що знаходяться на складі).

$B_{\text {оч }}$ и $B_{N}$ визначаються шляхом калькуляції. $A_{\text {н }}$ и $A_{\text {c }}$ визначаються методами теорії масового обслуговування для конкретних умов виробничої діяльності та залежать від кількості оборотних агрегатів $N$.

Якщо верстати надходять на ремонт (заміну агрегату) 3 інтенсивністю $\lambda$, а середній час повернення агрегату на склад складає $T_{\text {об }}=1 / \mu$, то для розімкнутої системи масового обслуговування 3 очікуванням маємо наступні розрахункові формули (для спрощення формул використовуються вирази $a=\lambda \mu$, завантаження $\beta=a / n)$.

Ймовірність того, що всі обслуговуючі апарати (агрегати) вільні:

$$
P_{0}=\frac{1}{\sum_{k=0}^{N-1} \frac{a^{k}}{k !}+\frac{a^{N}}{N !(1-\beta)}}
$$

Ймовірність того, що всі обслуговуючі апарати (агрегати) зайняті:

$$
P_{\mathrm{H}}=\frac{P_{0}}{N !(1-\beta)}
$$

Середня кількість вимог (верстатів):

$$
A_{\mathrm{H}}=\frac{P_{\mathrm{H}} q}{(1-\beta)^{2}}
$$

Середня кількість вільних апаратів, що обслуговують (агрегатів):

$$
A_{\mathrm{c}}=\sum_{k=0}^{N-1} \frac{N-k}{k !} a^{k}=N-a
$$

Початкове розрахункове число оборотних агрегатів визначається за умовою а $\leq N_{\min }$.

Зміною кількості оборотних агрегатів від $N_{\min }$ до $N$ визначаємо оптимальну кількість оборотних агрегатів з умов цільової функції:

$$
B_{\text {оч }} A_{\text {н }}+B_{N} A_{c} \rightarrow \min
$$

Розрахунок параметрів функціонування СМО доцільно здійснювати на ЕОМ.

Для проведення аналізу роботи ремонтних вузлів були отримані дані за місяць роботи машинобудівного цеху. Кожна заявка на обслуговування обладнання реєструється в єдиній базі. Далі заявки сортуються на декілька типів: заміна обладнання, ремонт на місці, направлення обладнання на ремонт до ремонтного вузла. Формування навантаження на ремонтний вузол залежить від кількості обладнання, що за місяць було спрямовано на обслуговування.

В процесі аналізу було виявлено вихідні параметри $\lambda=1 ; T_{\text {об }}=3 ; B_{\text {оч }}=15 ; B_{N}=5$; приведена інтенсивність $A=3, N$ - кількість каналів (агрегатів) обслуговування.

На рисунку 2 наведено алгоритм роботи програми. 


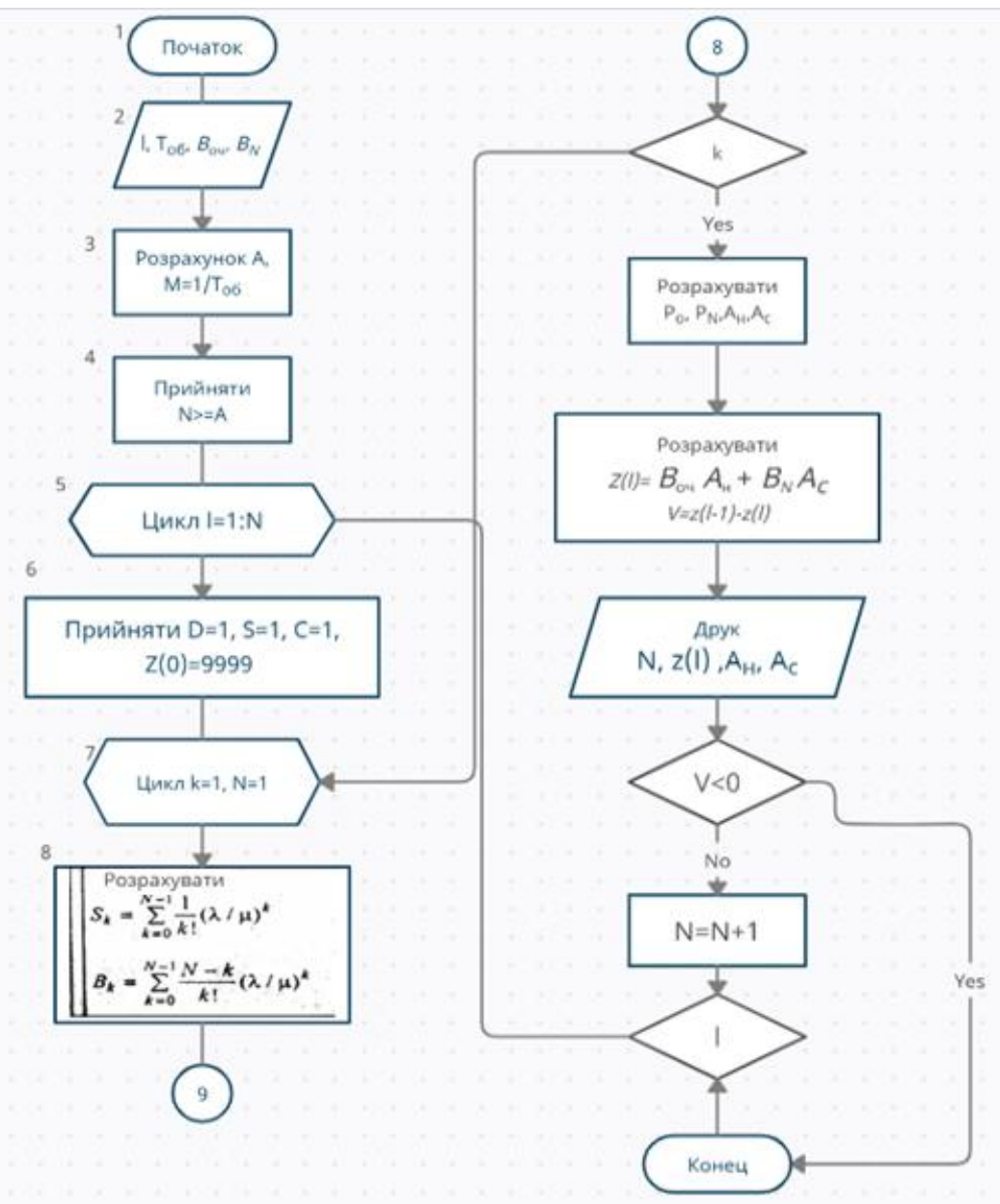

Рис. 2. Алгоритм роботи програми

На основі запропонованого алгоритму було розроблено програмний продукт у середовищі програмування Delphi 7. Таке програмне забезпечення виконує розрахунок основних показників та аналізує отриману інформацію (рис. 3).

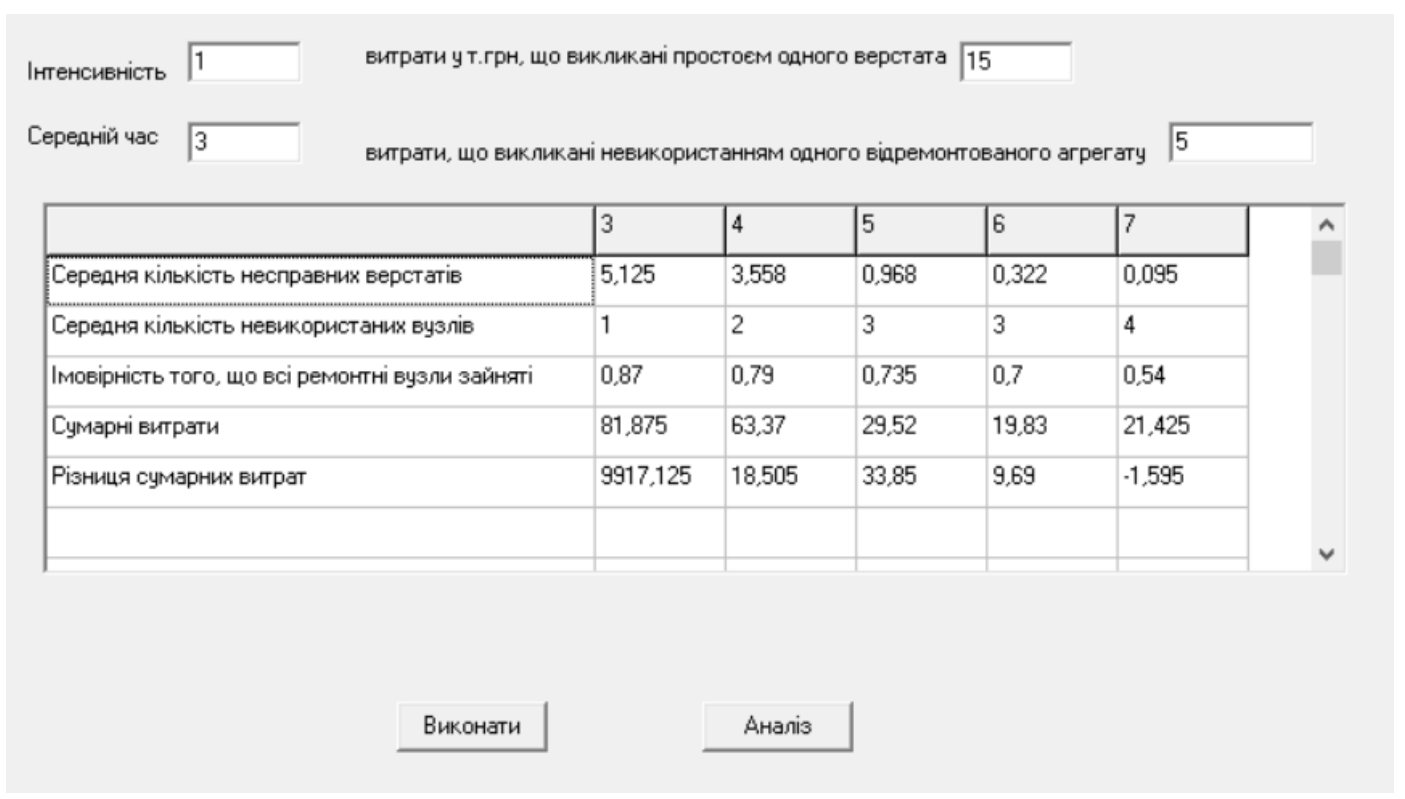

Рис. 3. Результати розрахунків за програмою 
Аналіз отриманих результатів показав, що найбільш оптимальним є використання 6 ремонтних вузлів. При цьому маємо найменші загальні витрати на обслуговування та середню зайнятість вузлів. Збільшення ремонтних вузлів призводить до збільшення витрат і збільшення імовірності простою каналів.

Графічний аналіз отриманих результатів представлено на рисунку 4.

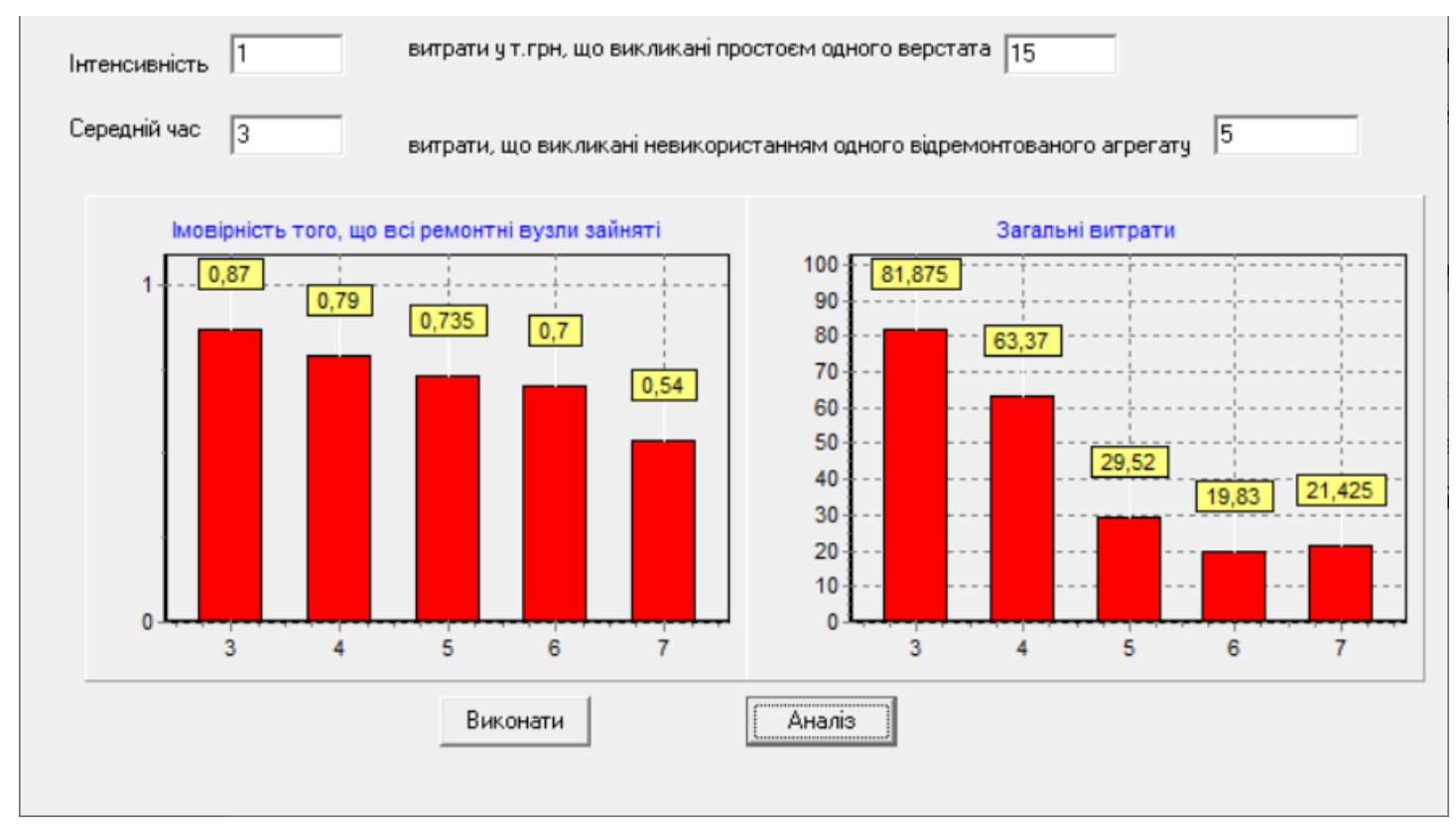

Рис. 4. Графічний аналіз отриманих результатів

Аналізуючи перший графік, видно, що при збільшенні кількості ремонтних вузлів загальне навантаження падає і при кількості вузлів 7 в роботі зайняті тільки половина каналів. Дані другого графіку дозволяють користувачу програми проаналізувати залежність витрат від кількості ремонтних вузлів. Як бачимо на рисунку, витрати зменшуються до певного рівня у 6 каналів, далі витрати починають збільшуватися, оскільки падає навантаження на ремонтні вузли. Можна зробити висновок, що оптимальною кількістю каналів для вказаних вхідних даних $є 6$ шт., оскільки при такій кількості каналів підприємство має мінімальні витрати у розмірі 19,83 т. грн.

Висновки та перспективи подальшого дослідження. Таким чином, було досліджено процес управління технічним обслуговуванням та ремонтом обладнання машинобудівного підприємства та доведено ефективність застосування теорії систем масового обслуговування для вирішення такої задачі. Основні показники СМО дозволяють виконати аналіз та оптимізувати процес ремонту за умови економії витрат робочого часу. За результатами розрахунків є можливість обрати необхідну кількість обслуговуючих агрегатів для ремонту непрацюючих верстатів на машинобудівному підприємстві при мінімальних витратах на обслуговування.

\section{Список бібліографічного опису}

1. Бусленко Н. П. Моделирование сложных систем. 2-е изд., перераб. - М.: Главная редакция физикоматематической литературы изд-ва "Наука", 1978. - 400 с.

2. Гнеденко Б. В. Введение в теорию массового обслуживания [Текст] / Б. В. Гнеденко, И. Н. Коваленко. - M.: URSS: Ком. книга, 2005. - 135 с.

3. Кениг Д., Штойян Д. Методы теории массового обслуживания: Пер. с нем. / Под ред. Г. П. Климова. - М .: Радио и связь, 1981. - 128 с, ил.

4. Клейнрок Л. Вычислительные системы с очередями / Л. Клейнрок. - М.: Мир, 1979. - 600 с.

5. Нечволода Л.В. Информационные технологии поддержки принятия решений технического переоснащения машиностроительного предприятия/ дис. на соиск. ученой степени к.т.н. - Донецк, 2011.

6. Новиков О.А. и др. Прикладные вопросы теории массового обслуживания. М.: «Советское радио», 1969. - 400 с.

7. Овчаров Л. А. Прикладные задачи теории массового обслуживания / Л. А. Овчаров. - М. : Машиностроение, 1969. $-324 \mathrm{c}$.

8. Советов Б. Я., Яковлев С.А. Моделирование систем: Учеб. для вузов - 3-е ид., перераб. и доп. - М.: Высш. шк., 2001. - 343 с: ил.

9. Теорія систем масового обслуговування: навч. посібник / А. Л. Литвинов ; Харків. нац. ун-т міськ. госп-ва ім. О. М. Бекетова. - Харків : ХНУМГ ім. О. М. Бекетова, 2018. - 141 с. 
10. Хинчин А.Я. Работы по теории массового обслуживания / А.Я. Хинчин; под ред. Б.В. Гнеденко. - М.: УРСС, 2004. $-267 \mathrm{c}$.

11. Чистякова Т. Моделювання роботи системи масового обслуговування виробничих процесів// Наукові записки молодих вчених [Електронний ресурс] - Режим доступу: https://phm.cuspu.edu.ua/ojs/index.php/SNYS/article/view/1449

\section{References}

1. Buslenko N.P. Modeling of complex systems. 2nd ed., redesign. Moscow, Main edition of the physical and mathematical literature of the publication "Nauka", 1978. 400 p. (in Russian)

2. Gnedenko B.V., Kovalenko I.N. Introduction to queuing theory. Moscow, URSS: Com. book, 2005. 135 p. (in Russian)

3. Kenig D., Shtoyyan D. Queuing theory methods. (Russ.ed.: Klimova G.P., Moscow, Radio and communications, 1981. 128 p., ill.).

4. Kleinrock L. Queuing systems. Vol.2. Computer Application. New York, Wiley (Russ.ed.: Tsybakov V.S., Moscow, Mir, 1979. 600 p.).

5. Nechvoloda L.V. Information technologies for support of decision making of technical re-equipment of engineering enterprise. PhD diss. Donetsk, 2011. 216 p. (in Russian)

6. Novikov O.A Applied issues of queuing theory. Moscow, Soviet Radio, 1969. 400 p. (in Russian)

7. Ovcharov L.A. Applied problems of queuing theory. Moscow, Mashinostroenie, 1969. 324 p. (in Russian)

8. Sovetov B.E., Yakovlev S.A. Modeling of systems: for universities. 3rd ed., redesign. Moscow, Vyisshaya shkola, 2001. 343 p., ill. (in Russian)

9. Litvinov A.L. Theory of queuing systems: tutorial. Kharkiv, O.M.Beketov National University of Urban Economy, 2018. 141 p. (in Ukrainian)

10. Hinchin A.Ya., Gnedenko B.V. Works on queuing theory. Moscow, URSS, 2004. 267 p. (in Russian)

11. Chistyakova T. Modeling of work of queuing systems of production processes. Scientific notes of young scientists Available at: https://phm.cuspu.edu.ua/ojs/index.php/SNYS/article/view/1449 (accessed 10 April 2021). 